Sustinere

Journal of Environment and Sustainability

Volume 2 Issue 3 (2018) 118-127

Print ISSN: 2549-1245 Online ISSN: 2549-1253

Website: https://sustinerejes.comE-mail:sustinere.jes@iain-surakarta.ac.id

RESEARCH PAPER

\title{
Subsidence analysis in DKI Jakarta using Differential Interferometry Synthetic Aperture Radar (DInSAR) Method
}

\author{
Cyntia, I Putu Pudja* \\ Dept. of Geophysics, State College of Meteorology Climatology and Geophysics, Tangerang, Indonesia \\ Article history: \\ Received 4 November 2018 | Accepted 29 December 2018 | Available online 31 December 2018
}

\begin{abstract}
Land subsidence in DKI Jakarta influenced by several key factors, including the number of buildings that increase the load above the surface. There are still many people who explore groundwater sources as the principal source of clean water. Also, the soil type is dominated by alluvial. This alluvial deposit can be one of the parameters for soil deformation in the form of land subsidence and uplift in land surface because basically, alluvial soil types have a susceptibility to the load support power above. So that the land subsidence in DKI Jakarta is relatively continuous. To find out the land subsidence is used a high-tech method, Differential Interferometry Synthetic Aperture Radar (DInSAR) satellite image of radar data (SAR Sentinel-1A) in 2017. The result shows the land subsidence in the average value of DKI Jakarta which is about $-3.685 \mathrm{~cm} /$ year and the highest subsidence happened in the West Jakarta district about $-5.850 \mathrm{~cm} /$ year in average.
\end{abstract}

Keywords: land subsidence; DKI Jakarta; DInSAR method; Sentinel-1A

\section{Introduction}

Daerah Khusus Ibukota (DKI) Jakarta as a metropolitan city of Indonesia with a total land area of $662.33 \mathrm{~km}^{2}$ is inhabited by about $10,177,924$ (BPS, 2015) people which quantitatively this number represents $4 \%$ of the total population of Indonesia. This population density indicates that the population living in DKI Jakarta is threatened due to the subsidence.

Based on the causes, there are three main factors that can accelerate land subsidence, among others: natural factor (geology); groundwater retrieval factor; and mass building factor (Abidin et al., 2001; Murdohardono \& Sudarsono, 1998). This excessive groundwater retrieval was believed to be one of the main factors leading to the land subsidence (Soekardi et al., 1986). This happened because there were still many citizens of DKI Jakarta who had not switched to using Perusahaan Air Minum (PAM) water (Delinom, 2015).

${ }^{*}$ Corresponding author. E-mail: iputu.pudja@stmkg.ac.id

DOI 10.22515/sustinere.jes.v2i3.48 
Some researchers who had surveyed land subsidence with various methods between 1982 and 2011 (Abidin et al., 2013) (flat plot survey, GPS survey, and InSAR), stated that DKI Jakarta had experienced a subsidence rate between $1-15 \mathrm{~cm} /$ year and could reach $20-25 \mathrm{~cm} /$ year in some locations within a certain time. Ferrina (2015), after conducting a study on land subsidence in Jakarta by time-lapse gravity anomaly method in the period of 2013 - 2014 concluded that generally, land subsidence occurred at $2.5 \mathrm{~cm}$ in Central Jakarta, $17 \mathrm{~cm}$ in Kebayoran area, South Jakarta, and land uplifted of $2 \mathrm{~cm}$ in North Jakarta.

Therefore, further research on land subsidence to determine the value of the latest range in DKI Jakarta is highly demanded. One of the high technology-based methods used to analyze the subsidence is Differential Interferometric Synthetic Aperture Radar (DInSAR) is a remote sensing technique with Sentinel-1A satellite images in 2017. Data from DInSAR in the form of DEM (Digital Elevation Model) was used to create a land subsidence map.

\section{Literature review}

\subsection{DInSAR method}

Differential Interferometric Synthetic Aperture Radar (DInSAR) is a method of radar imaging to the side by utilizing phase difference of two or more SAR images with different process acquisitions to obtain topography and deformation (Al-Akbar et al., 2015).

The DInSAR technique uses two SAR images to identify the spatial changes of an area that utilizes coherent interferometric phase measurements of the same surface. The phase difference produces a new type of image called an interferogram. AN interferogram will show whether the studied areas are experiencing land subsidence or land uplift (Francis et al., 1996).

The interferometric phase $(\Delta \varphi)$ generated by InSAR consists of five-phase signal contributions: $\Delta \varphi_{-}$flat is the phase affected by the topographic, $\Delta \varphi_{-}$elevation is the phase influenced by the altitude, $\Delta \varphi_{-}$deformation is the phase affected by changes in the surface (deformation), $\Delta \varphi_{-}$atmosfer is the phase influenced by the atmosphere, and $\Delta \varphi \_n o i s e$ is the phase affected by the noise (ESA, 2007). Here was the phasing formula used in the DInSAR method:

$$
\begin{gathered}
\Delta \varphi=\Delta \varphi_{\text {flat }}+\Delta \varphi_{\text {elevasi }}+\Delta \varphi_{\text {deformation }}+\Delta \varphi_{\text {atmosfer }}+\Delta \varphi_{\text {noise }} \\
\Delta \varphi_{\text {flat }}=-\frac{4 \pi}{\lambda} \frac{B_{n}}{R \tan \theta} \\
\Delta \varphi_{\text {elevasi }}=-\frac{\Delta q}{\sin \theta} \cdot \frac{B_{n}}{R} \cdot \frac{4 \pi}{\lambda} \\
\Delta \varphi_{\text {deformation }}=\frac{4 \pi}{\lambda} d
\end{gathered}
$$

Where $\lambda=$ wavelength $(\mathrm{m})$

$B_{n}=$ baseline perpendicular $(\mathrm{m})$

$R$ = radar distance to target $(\mathrm{m})$

$\theta=$ incident angle (degree)

$q=$ altitude difference between target $(\mathrm{m})$

$d=$ relative displacement of slant projection $(\mathrm{m})$ 


\subsection{Sentinel-1A}

Sentinel-1A is a European radar imaging satellite launched in 2014. This is the first Sentinel-1 satellite to be launched as part of the EU Copernicus programs. This satellite carries a Radar Aperture C-band with a frequency of $5.405 \mathrm{GHz}$ and captures images in the same region with an interval of 12 days at an orbital height of $693 \mathrm{~km}$ and an inclination of $98.18^{\circ}$. C-band waves are most useful for undeveloped forests and rare canopies. It can also map the extent of swamp puddles in the lowlands of Roanoke (Bourgeau-chavez et al., 2009). Furthermore, it can track all aspects of the environment, ranging from oil spills, sea ice, to ground movements. It can also do mapping on land use and land deformation changes (subsidence). The product data generated by Sentinel-1A satellites are divided into four acquisition modes (spatial resolution), presented in Table 1.

Table 1. Spatial resolution product

\begin{tabular}{lc}
\hline \multicolumn{1}{c}{ Spatial resolution } & Spatial resolution size \\
\hline Strip Map (SM) mode: $80 \mathrm{~km}$ swath & $5 \mathrm{~m} \times 5 \mathrm{~m}$ \\
Interferometric Wide (IW) swath: $250 \mathrm{~km}$ swath & $5 \mathrm{~m} \times 20 \mathrm{~m}$ \\
Extra Wide (EW) swath mode: $400 \mathrm{~km}$ swath & $25 \mathrm{~m} \times 100 \mathrm{~m}$ \\
Wave (WV) mode: $20 \mathrm{~km} \times 20 \mathrm{~km}$ & $5 \mathrm{~m} \times 20 \mathrm{~m}$ \\
\hline
\end{tabular}

The products available on Sentinel-1A are VV polarization and VH polarization with both ascending and descending satellite paths. The available data also varies and has different characters. Here are the data products and image characteristics Sentinel-1A (ESA, 2015) (Tabel 2).

Table 2. Sentinel-1A characteristic products

\begin{tabular}{lcl}
\hline \multicolumn{1}{c}{ Sentinel-1A product } & Data size & \multicolumn{1}{c}{ Characteristics } \\
\hline Level-0 Raw Data & $1 \mathrm{~GB}$ & Raw data \\
Level-1 SLC & $8 \mathrm{~GB}$ & Consists of amplitude and phase \\
Level-1 GRD & $1 \mathrm{~GB}$ & $\begin{array}{l}\text { Consists of amplitude with multi-look intensity } \\
\text { Level-2 Ocean }\end{array}$ \\
& & $\begin{array}{l}\text { Consists of three parameters for geophysics } \\
\text { (currents, waves, wind direction) }\end{array}$ \\
\hline
\end{tabular}

\section{Methodology}

\subsection{Research area}

The study area of this research was DKI Jakarta, the capital city of Indonesia with longitude and latitude at $106^{\circ} 22^{\prime} 42^{\prime \prime} \mathrm{E}-106^{\circ} 58^{\prime} 18^{\prime \prime} \mathrm{E}$ and $5^{\circ} 19^{\prime} 12^{\prime \prime} \mathrm{S}-6^{\circ} 23^{\prime} 54^{\prime \prime} \mathrm{S}$, respectively. The province has five districts namely North Jakarta, West Jakarta, Central Jakarta, East Jakarta, and South Jakarta which are presented in Figure 1. 


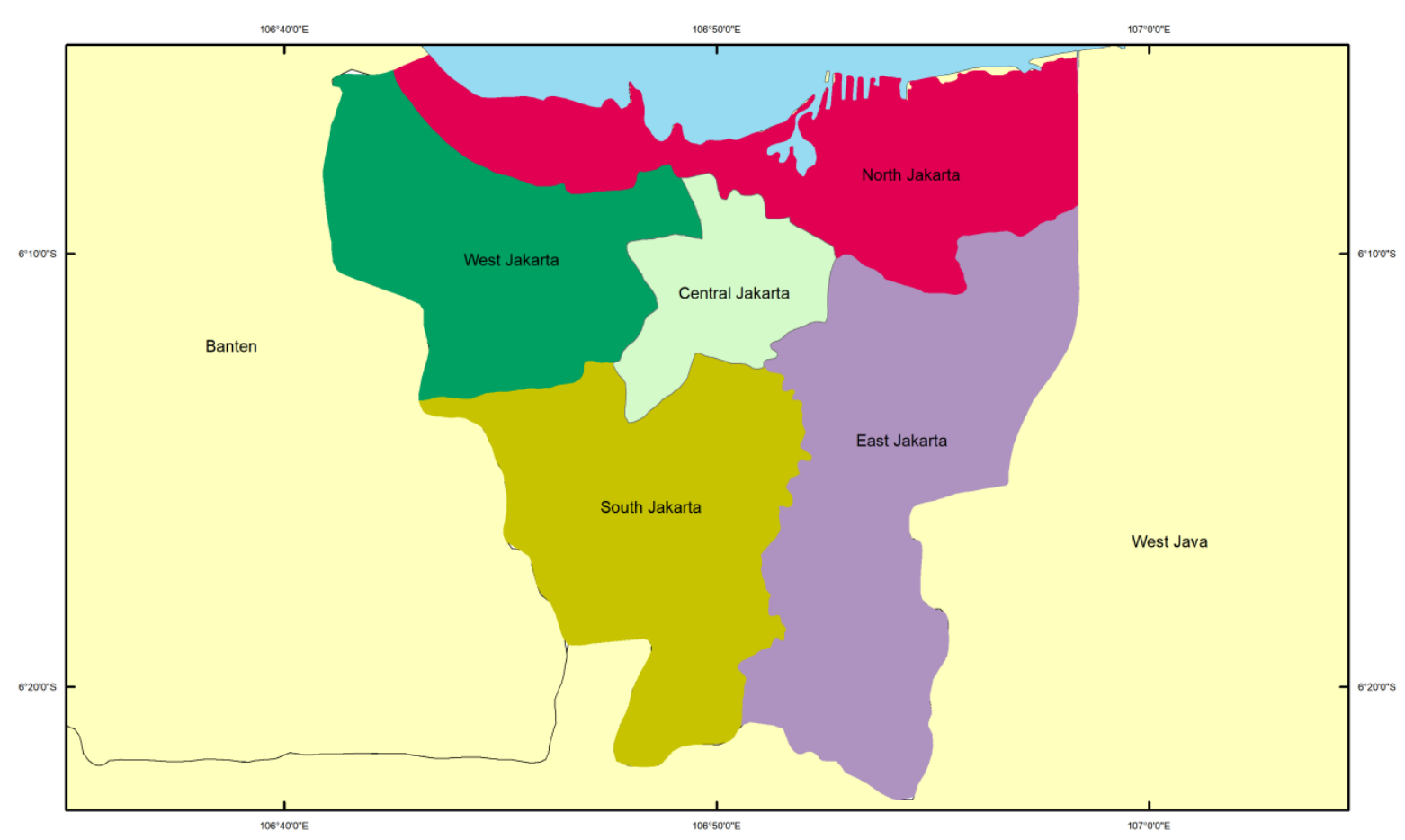

Figure 1. DKI Jakarta administration map

\subsection{Data and its processing}

The data using Sentinel-1A radar in 2017 was downloaded from Alaska Satellite Facility (ASF) and described in Table 3 and Table 4. The data that has been collected was then processed in a special software called SNAP that could be operated on Windows and Linux, and SNAPHU that could only be operated in Linux. The final result was the Digital Elevation Model (DEM) which was used to create a land subsidence map to show deformation changes in the area of DKI Jakarta. Field validation was not applied to check the accuracy of the land subsidence, but the data was verified again based on measurements on some previous studies.

Table 3. Sentinel-1a images data

\begin{tabular}{cccccc}
\hline No. & Acquisition date & Level & Acquisition mode & Polarization & Viewpoint \\
\hline 1. & $2017 / 01 / 17$ & 1.0 & IW & VV & Ascending \\
2. & $2017 / 12 / 07$ & 1.0 & IW & VV & Ascending \\
\hline
\end{tabular}

Table 4. Sentinel-1a images couple data

\begin{tabular}{ccccc}
\hline Mst/Slv & Acquisition & Track & Baseline perpendicular (m) & Baseline temporal (days) \\
\hline Master & $2017 / 01 / 17$ & 98 & 0 & 0 \\
Slave & $2017 / 12 / 07$ & 98 & 54.76 & -324 \\
\hline
\end{tabular}




\subsection{Research procedure}

Stages carried out during conducting the research are revealed in Figure 2. The data obtained was then paired with each other and every pair had its own master and slave data. This meant that in one pair, there were two satellite data. The point to consider in determining the satellite pair was to ensure that the master and slave baseline perpendicular estimates were not too large to avoid poor inter-data coherence. This information could be viewed on the InSAR Stack Overview menu in the SNAP software.

The next process in the SNAP software included image correction to unite between master and slave pixels. The image obtained had three sub-swaths (IW1, IW2, and IW3). Each sub-swath consisted of 9-10 burst. In this study, the area of DKI Jakarta was in IW2 and 3 bursts on each pair of images were selected. Sub-swath and burst were selected in accordance with the research area. In this stage, the process of orbital correction with Sentinel Precise and backgeocoding stages with DEM SRTM 3 sec were downloaded automatically using bilinear interpolation resampling method (imaging method to increase or decrease the number of pixels in the digital image to produce a good image).

Following that stage, interferogram and coherence were determined. The smaller the coherence value the lower the level of compatibility between the image (Hartl, 1996). If the coherence value was more than 0.2 then it could be continued to the next stage. However, the average coherence value that was often obtained was about 0.3 so it could be continued with the process of TOPSAR Deburst. This stage merged the third burst separated by a black line.

To be more focused on the considered research area, which in this case was DKI Jakarta, the Subset was conducted after TOPSAR Deburst. This condition would reduce the duration of software running. Subsequent phase topographic removal was then carried out to do interferogram simulation based on the DEM reference and subtraction of the topographic phase of the interferogram being processed. In this step, we used DEM SRTM 3 sec which was automatically downloaded in SNAP software.

In the next interferogram, a filtering technique was applied to reduce the phase noise, ie Goldstein Filtering with the default setting of the SNAP feature. Once it reached the filter, the next step, Multilooking, which served to reduce the noise of SAR image by forming pixels near the square, was then conducted. However, the phases were already processed when Multilooking still contained ambiguity. Therefore, it was necessary to eliminate the ambiguity phase and transform it into an absolute phase. This process, called Unwrapping Phase, was carried out in SNAPHU software with Linux operating system. Previously, to enter the process into SNAPHU, results of multilooking stage needed to be unwrapped in SNAP software. Once the SNAPHU process completed, the process could be continued to the unwrap import setting in the SNAP.

The next procedure was to convert the unwrap data into displacement phase to find out the difference of DInSAR processor to do the conversion from a slant to height using Phase to Displacement in SNAP software. The next step was geocoding, in SNAP called Terrain Correction Doppler Range. 


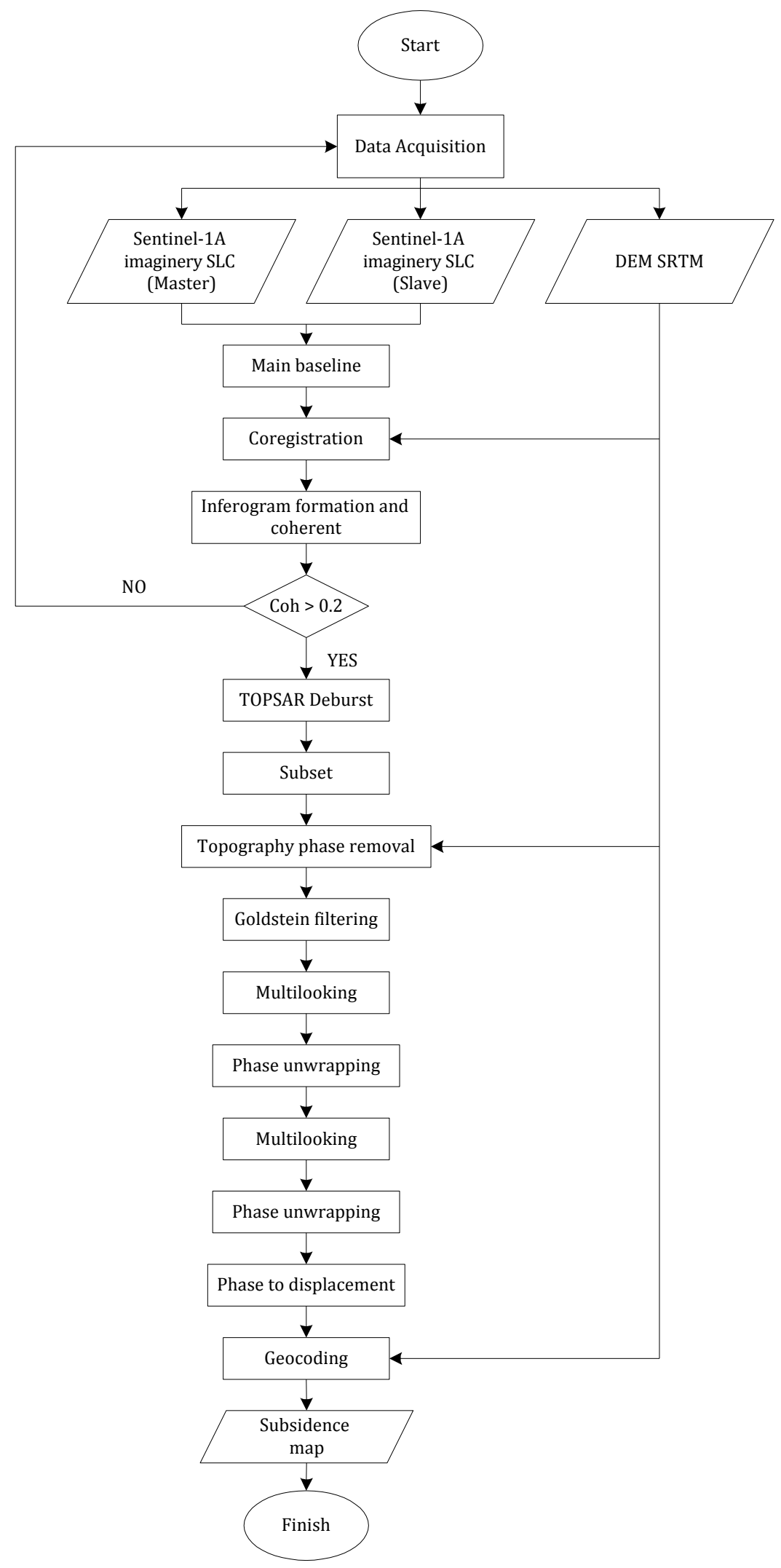

Figure 2. Research methodology flowchart 


\section{Results and discussions}

The results obtained by using Sentinel-1A data of 2017 can be seen in Figure 2, while the breakdown of land subsidence value is shown in Table 5 .

\subsection{Research results analysis}

Figure 3 shows the land subsidence occurring in DKI Jakarta under study over a period of time using the DInSAR method and Sentinel-1A radar satellite data in 2017. The red colour is a representation of the height of -12 to $-5.0 \mathrm{~cm} /$ year, the yellow colour indicates the height of -5.0 to $2.0 \mathrm{~cm}$ /year and the green colour shows the height of 2.0 to $10 \mathrm{~cm} /$ year.

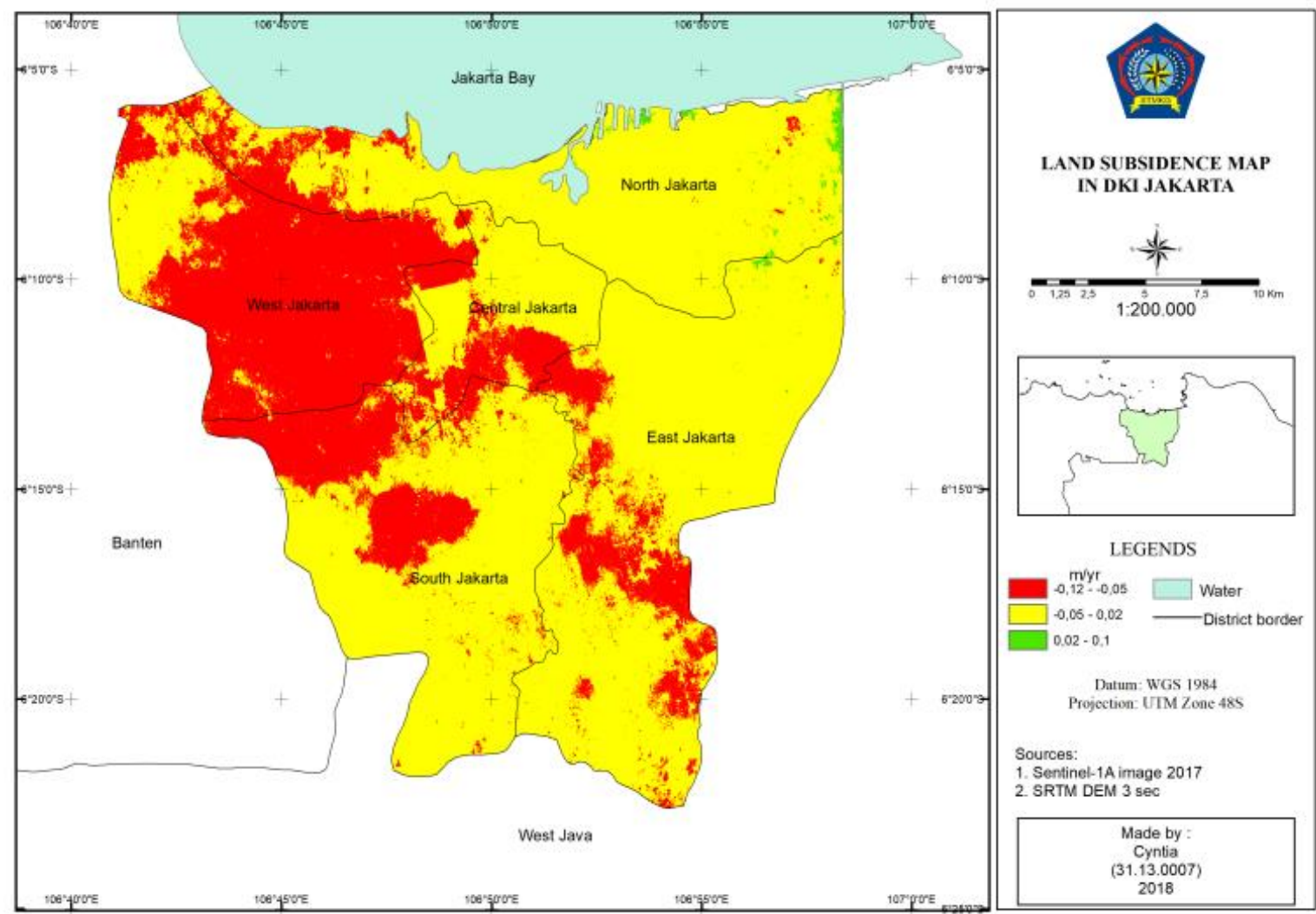

Figure 3. Land subsidence using DInSAR method

Table 5. Land Subsidence in DKI Jakarta Using DInSAR Method

\begin{tabular}{lccc}
\hline \multicolumn{1}{c}{ Districts } & $\begin{array}{c}\text { Average } \\
\text { (cm/year) }\end{array}$ & $\begin{array}{c}\text { Minimal } \\
\text { (cm/year) }\end{array}$ & $\begin{array}{c}\text { Maximum } \\
\text { (cm/year) }\end{array}$ \\
\hline North Jakarta & -2.006 & -12.154 & 9.505 \\
West Jakarta & -5.850 & -12.687 & 0.924 \\
Central Jakarta & -4.365 & -11.388 & 1.635 \\
East Jakarta & -2.930 & -11.304 & 5.860 \\
South Jakarta & -4.186 & -10.221 & 2.261 \\
DKI Jakarta (Province) & -3.685 & -12.687 & 9.505 \\
\hline
\end{tabular}


Overall, the land subsidence in 2017 occurred in all areas of DKI Jakarta (yellow colour) with various values and the average of $-3.685 \mathrm{~cm} /$ year. Based on Figure. 3, the land subsidence tended to be diagonally larger from northwest to southeast (red colour), that is located in the western part of North Jakarta district, most of West Jakarta and from north to central district of South Jakarta, south of Central Jakarta district, and from central to southeast of East Jakarta district. While the green colour which indicates that there was dominant uplift and was seen very little is located on the border between North Jakarta and West Java province. Based on Table V, it can be seen that the highest land subsidence occurred in West Jakarta regency with the value of $-12.687 \mathrm{~cm} /$ year with the average value of land subsidence $=-5.850 \mathrm{~cm} /$ year, while the highest land uplift happened in North Jakarta regency with the value of $9.505 \mathrm{~cm} /$ year with the average value of land subsidence was $-2.006 \mathrm{~cm} /$ year.

\subsection{Verification}

To find out whether the DInSAR method is good for monitoring land subsidence in DKI Jakarta, previous research results were verified. Verification was conducted on the results of the study of land subsidence measurements with the GPS method of 1997 and 1999 (Abidin et al., 2001) that can be seen in Table 6.

Table 6. Land subsidence verification in DKI Jakarta

\begin{tabular}{lcc}
\hline \multicolumn{1}{c}{ Point } & GPS (cm/year) & $\begin{array}{c}\text { DInSAR } \\
\text { (cm/year) }\end{array}$ \\
\hline North Jakarta & -1.1 to -11.3 & -2.0 \\
West Jakarta & -3.6 to -4.8 & -5.8 \\
Central Jakarta & -6.4 & -4.4 \\
East Jakarta & -1.3 to -2.8 & -2.9 \\
South Jakarta & -0.9 to -4.8 & -4.2 \\
\hline
\end{tabular}

There were differences among research results yet it was not too far based on the average calculation. The difference was affected on several factors, including groundwater intrusion and building load.

\subsection{Prospect of DInSAR method in geophysics field}

The DInSAR method utilized remote sensing to estimate temporal and spatial surface movements due to ground deformations, to obtain a wide and great accuracy of data monitoring and coverage. Another advantage of this method was that DInSAR could be used to set up monthly or annual monitoring service with moderate cost. Considering this potential, the DInSAR method could be utilized for research in the field of geophysics, e.g. ground deformation (subsidence), deformation between hanging wall and footwall (fault), and supporting data for field observation (gravity, GPS, etc).

\section{Conclusions}

Based on the results, DKI Jakarta had average land subsidence $-3.685 \mathrm{~cm} /$ year with the highest land subsidence range of $-12.687 \mathrm{~cm} /$ year and the highest uplift of $9.505 \mathrm{~cm} /$ year. The average land subsidence in,West Jakarta, experienced the worst land subsidence on average - 
$5.850 \mathrm{~cm} /$ year, North Jakarta on average $-2.006 \mathrm{~cm} /$ year, Central Jakarta average -4.365 $\mathrm{cm} /$ year, and East Jakarta average $-2.930 \mathrm{~cm} /$ year, and South Jakarta average of $-4.186 \mathrm{~cm} /$ year.

Based on the verification, DInSAR method can be used to monitor subsidence land in DKI Jakarta with good accuracy, at any time, and with the moderate cost so that monitoring is possible done in a monthly and annual basis.

\section{Acknowledgement}

The authors would like to thank the EU Copernicus program which had provided free Sentinel1A satellite radar data. We would also like to show our gratitude to Zainab Ramadhanis and members of ESA Forum for their pearls of wisdom during this research was being conducted, and we thank "anonymous" reviewers for their so-called insights.

\section{References}

Abidin, H. Z., Darmawan, D., Meilano, I., Kasuma, M. A., Kahar, J., Cecep, S., ... Sudibyo, Y. (2001). Land subsidence of Jakarta (Indonesia) and its geodetic monitoring system. Natural Hazards, 23(2-3), 365-387.

Abidin, H. Z., Gumilar, I., Andreas, H., Sidiq, T. P., \& Fukuda, Y. (2013). On the roles of geospatial information for risk assessment of land subsidence in urban areas of Indonesia. In $\mathrm{S}$. Zlatanova, R. Pieter, A. Dilo, \& H. Scholten (Eds.), Intelligent systems for crisis management (pp. 277-288). Berlin Heidelberg: Springer.

Al-Akbar, T. O., Prasetyo, Y., \& Wijaya, A. P. (2015). Analisis dampak penurunan muka tanah terhadap tingkat ekonomi menggunakan kombinasi metode DInSAR dan SIG (Studi kasus: Kota Semarang). Jurnal Geodesi Undip, 4(4), 136-143.

Bourgeau-chavez, L., Riordan, K., Miller, N., \& Nowels, M. (2009). Improving wetland characterization with multi-sensor, multi-temporal SAR and optical/infrared data fusion. Advances in Geoscience and Remote Sensing, 679-708.

BPS. (2015). Data Statistik Provinsi DKI Jakarta. Retrieved from https://jakarta.bps.go.id

Delinom, R. M. (2015). Ancaman bawah permukaan Jakarta: Tak Terlihat, Tak Terpikirkan, dan Tak Terduga. Jakarta: LIPI Press.

ESA. (2007). Part A InSAR processing: Guidelines for SAR interferometry processing and interpretation (tutorial). Netherlands: ESA Publications.

ESA. (2015). What is Sentinel-1? Retrieved from https://earth.esa.int/ web/guest/missions/esaoperational-eo-missions/sentinel-1

Ferrina, Q. (2015). Analisa amblesan dan penurunan muka air tanah dengan metode anomali gravity antar waktu (Studi Kasus: Jakarta). Sekolah Tinggi Meteorologi Klimatologi dan Geofisik.

Francis, P. W., Wadge, G., \& Mouginis-Mark, P. J. (1996). Satellite monitoring of volcanoes. In R. Scarpa \& R. I. Tilling (Eds.), Monitoring and mitigation of volcano hazards (pp. 257-298). New York: Springer Verlag.

Hartl, P. (1996). Synthetic aperture radar, theory, and applications. Faculty of the Geodesy-Delf University of Technology.

Murdohardono, D., \& Sudarsono, Y. (1998). Land subsidence monitoring system in Jakarta. In Proceedings of Symposium on Japan-Indonesia IDNDR Project: Volcanology, Tectonics, Flood 
and Sediment Hazards (pp. 243-256). Bandung.

Soekardi, P., Djaeni, A., Soefner, H., Hobler, M., \& Schmidt, G. (1986). Geological aspect of the aquifer system and the groundwater situation of the Jakarta Artesian Basin. In Seminar on Geological Mapping in the Urban Development, Economic and Social Commission for Asia and the Pacific. Bangkok. 